DOI: $10.2478 / \mathrm{v} .10169-011-0007-3$

\title{
VOLUME DENSITY AND LONGITUDINAL WAVE VELOCITY CHANGES OF THE CIĘŻKOWICE AND KROSNO FLYSCH SANDSTONES UNDER HIGH PRESSURE AND TEMPERATURE IN THE TRIAXIAL TEST CONDITION
}

\author{
J. PINIŃSKA ${ }^{1}$, A. DZIEDZIC ${ }^{2}$
}

\begin{abstract}
The poorly cemented Ciężkowice poorly sorted sandstone and the compact Mucharz fine grain sandstone have been laboratory tested at the triaxial compressing conditions in thermo-pressurized chamber of a rigid press MTS-815. The confining pressure: $\mathrm{P}=\sigma_{2}=\mathfrak{g} \sigma_{3}$ range from 0 to $96 \mathrm{MPa}$ and the temperature: $\mathrm{T}$ from $22^{\circ} \mathrm{C}$ to $120^{\circ} \mathrm{C}$ (simulated $500 \mathrm{~m}$ intervals from the surface to the depth of $3500 \mathrm{~m}$ ). During (the) each test, the characteristics of deformation and the elastic wave velocity paths were simultaneously monitored. The volume density and longitudinal wave velocity showed a non-linear increase with the progress of simulated depth, a volume density growth by 1.6 to $4.0 \%$, and the elastic wave velocity up to $250 \%$ of the primary value (surface condition), dependable on loading path, phase of deformation, and varying type of lithology. That may lead to wide error margin in a determination of rock's engineering properties and also create discrepancies between the static parameters of rocks $\left(\mathrm{E}_{s t}, \mathfrak{g} v_{s t}\right)$ determined by standard laboratory load tests, and the dynamic parameters $\left(\mathrm{E}_{d}, v_{d}\right)$ determined from the wave velocity and volume density.
\end{abstract}

Key words: great depth, high pressure, temperature, volume density, longitudinal wave velocity, sandstones, triaxial tests.

Rock volume density, being one of the most common geotechnical parameters, increases nonlinearly with the burial depth, according to variable confining pressure and temperature. Apart from its important role in surface engineering, the rock density controls the velocity of elastic wave propagation, which is usable in identifying geomechanical rock properties at great depths $[1,4]$. In this respect, the Ciężkowice sandstone - poorly cemented and poorly sorted, and the compact Krosno fine grain sandstone (Fig. 1) were tested in a thermo-pressurized cell. Under triaxial conditions of a servo-controlled press MTS-815, the temperature, pressure and the elastic wave velocity were simultaneously monitored with the progress of the volume changes followed by growth of volumetric density.

\footnotetext{
${ }^{1}$ Professor, Faculty of Geology, Warsaw University Wydział Geologii Uniwersytetu Warszawskiego, Warszawa, Poland. e-mail: joanna.pininska@uw.edu.pl

${ }^{2}$ Ph.D. Faculty of Geology, Warsaw University Wydział Geologii Uniwersytetu Warszawskiego, Warszawa, Poland. e-mail: artur.dziedzic@uw.edu.pl
} 
a)

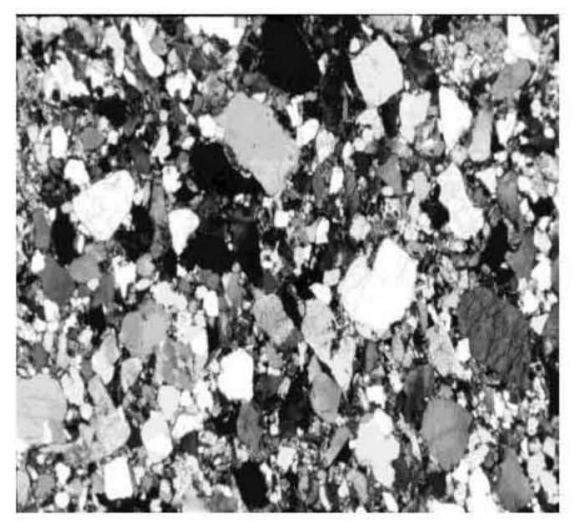

b)

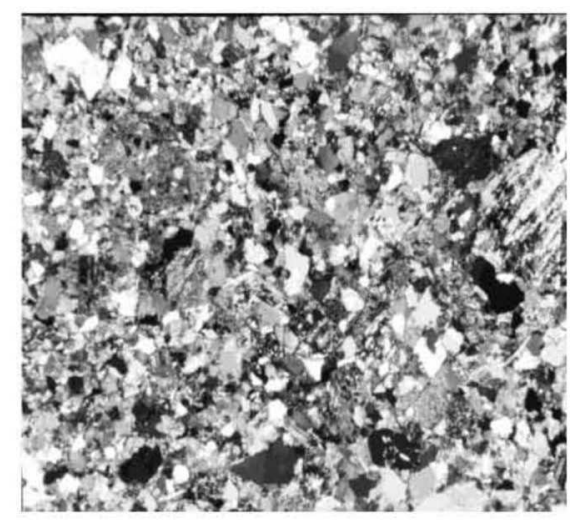

Fig. 1. Structure of tested sandstones. a) Coarse grained, poorly sorted sandstone of Ciężkowice with iron-clayey cementation; b) Medium grained, medium sorted sandstone of Krosno, carbonate cemented with numerous lithoclasts.

Rys. 1. Struktura badanych piaskowców. a) gruboziarnisty, słabo wysortowany piaskowiec ciężkowicki z żelazisto-ilastym spoiwem; b) średnioziarnisty, średnio wysortowany piaskowiec krośnieński, o spoiwie węglanowym, z licznymi litoklastami

The circumferential confining pressure $\mathrm{P}=\sigma_{2}=\sigma_{3}$ ranging from 0 to $90 \mathrm{MPa}$, and the temperature (T) increasing from $22^{\circ} \mathrm{C}$ (room temperature) up to $120^{\circ} \mathrm{C}$, simulated the $500 \mathrm{~m}$ intervals of depth between the surface to $3500 \mathrm{~m} \mathrm{bgl}$ (below ground level, Table 1). The confining pressure and temperature for each simulated depth variant were determined according to the average density of rock media at certain depths and regional geothermal gradient.

The changes of volume density $\left(\rho_{s}\right)$ were registered continuously up to the macro-dilatancy threshold, and changes of a longitudinal wave velocity $(\mathrm{Vp})$ were monitored up to maximum value for every simulated depth. The increasing pressure and temperature conditions $(\mathrm{P}+\mathrm{T})$ represented two stages of the triaxial state of stress:

Stage I: Unstable conditions - along with increasing confining pressure and temperature $(\mathrm{P}+\mathrm{T})$ up to each of simulated depths, and:

Stage II: Stable condition - due to stabilized $(\mathrm{P}+\mathrm{T})$ at the determined level with increasing axial loading.

The tested Ciężkowice and Krosno sandstones demonstrated the total maximum increase of volume density $\left(\Delta \rho_{s}\right)$ by 1.4 to $3.5 \%$, dependable on loading path and varying type of lithology.

General increase of volume density $\left(\Delta \rho_{s}[\%]\right)$ for each tested variant at the stages I and II are presented in Fig. 2.

In both types of sandstones major increase of density (of about $70-80 \%$ of the total) was noted at the stage $\mathrm{I}$, while $\mathrm{P}+\mathrm{T}$ was undergoing a stabilizing process and 
Test parameters.

Parametry badań

\begin{tabular}{|c|c|c|c|}
\hline Variant & $\begin{array}{c}\text { Depth } \\
\text { bgl }[\mathbf{m}]\end{array}$ & $\begin{array}{c}\mathbf{T} \\
{\left[{ }^{\circ} \mathbf{C}\right]}\end{array}$ & $\begin{array}{c}\text { P } \\
{[\mathbf{M P a}]}\end{array}$ \\
\hline 1 & 0 & 22 & 0 \\
\hline 2 & $\sim 500$ & 25 & 12 \\
\hline 3 & $\sim 1000$ & 30 & 25 \\
\hline 4 & $\sim 1500$ & 45 & 37 \\
\hline 5 & $\sim 2000$ & 60 & 50 \\
\hline 6 & $\sim 2500$ & 75 & 62 \\
\hline 7 & $\sim 3000$ & 90 & 75 \\
\hline 8 & $\sim 3500$ & 120 & 90 \\
\hline
\end{tabular}

Table 1

a) Ciezkowice sandstone

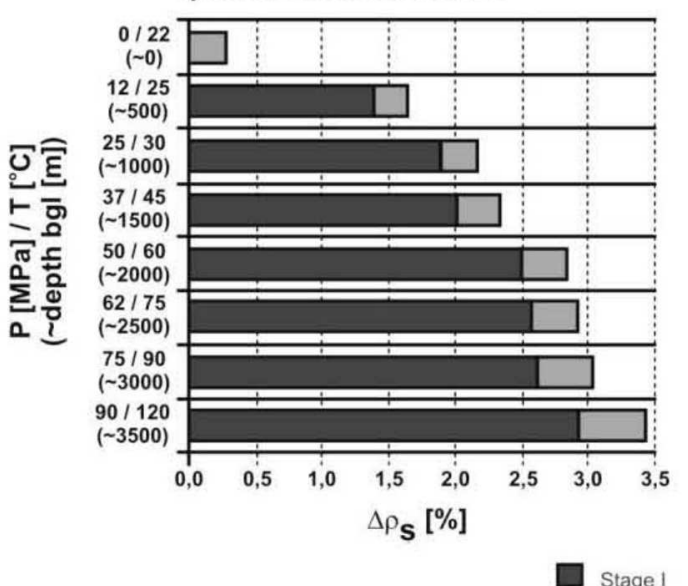

\section{b) Krosno sandstone}

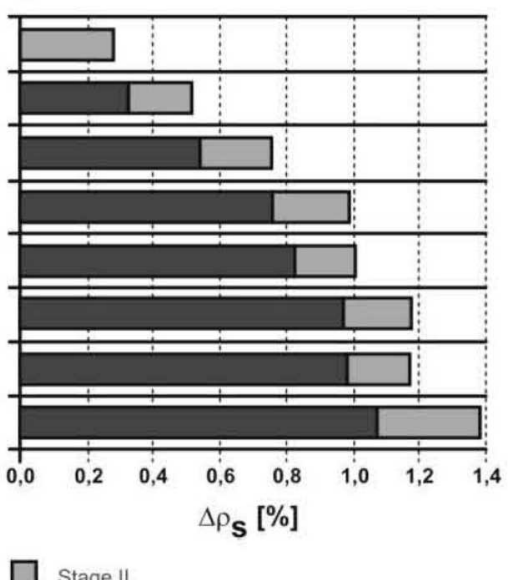

Fig. 2. Changes of average volume density $\left(\Delta \rho_{s}\right)$ at the stages I and II up to the macro-dilatancy thresholds at various levels of simulated depth $(\mathrm{P}+\mathrm{T})$. a) Ciężkowice sandstone, b) Krosno sandstone.

Rys. 2. Zmiany średnich wartości gęstości objętościowej $\left(\Delta \rho_{s}\right)$ na etapie I i II mierzone do progu makrodylatncji na poszczególnych poziomach symulowanej głębokości $(\mathrm{P}+\mathrm{T})$. a) piaskowiec ciężkowicki; b) piaskowiec krośnieński

after dynamic increase at the simulated depth interval 0 to $500 \mathrm{~m}$, the further increase of density $(\Delta \rho \mathrm{s} \%)$ was significantly diminishing. It could be also noted, that in the Ciężkowice sandstone the total volume density was growing slowly (Fig. 2a) while in the Krosno sandstone started to grow irregularly from the depth of approximately $2000 \mathrm{~m}$ and below (Fig. 2b). 
At the stage II, an increase in volume density is differentiated according to the depth and the phase of deformation (Fig. 3). The greatest changes appeared during the phase of nonlinear compaction (phase 1). In the Ciężkowice sandstone (Fig. 3a) a role of a compaction phase diminished in the growing density along the increase of simulated depth, while the role of elastic deformation increased in phases 2 and 3. In the Krosno sandstone (Fig. 3b), the role of compaction (phase 1), gradually decreased up to the $2000 \mathrm{~m}$ depth, then gradually increased with the growing depth, while the role of elastic phase remained semi-stable.
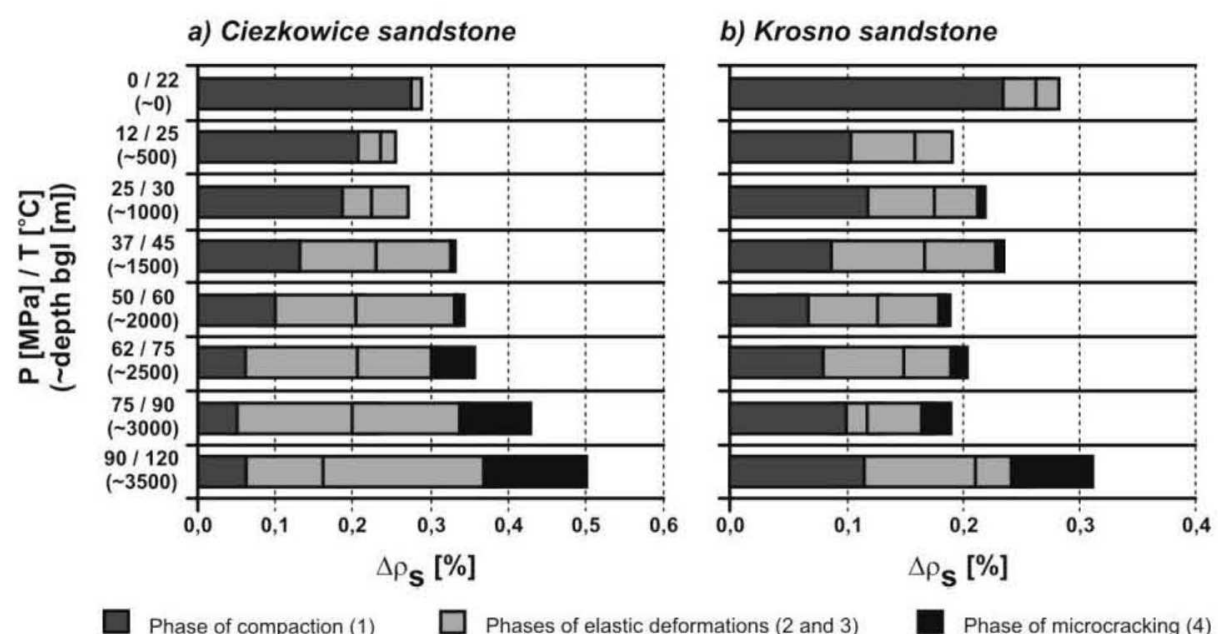

Fig. 3. Change of average volume density in the II stage at the subsequent phases of deformation at various levels of simulated depth $(\mathrm{P}+\mathrm{T})$. a) Ciężkowice sandstone, b) Krosno sandstone.

Rys. 3. Zmiany średnich wartości gęstości objętościowej na etapie II w poszczególnych fazach deformacji przedkrytycznej na kolejnych poziomach symulowanej głębokości $(\mathrm{P}+\mathrm{T})$. a) piaskowiec ciężkowicki; b) piaskowiec krośnieński

Significantly, at the simulated depth greater than $2000 \mathrm{~m}$ in both sandstones, the notable increase of a volume density appeared also, immediately before the threshold of macro-dilatancy (phase 4), what indicated an active reconstruction of a rock structure.

Generally, an increase of $\rho_{s}$ is variable according to actual $\mathrm{P}+\mathrm{T}$ (a depth) and phase of deformation, and a general resultant of volume density changes remain non-linearly variable. It should be noted that individual elements of a rock structure may also represent various phases of deformation.

The average total growth of volume density $\left(\Delta \rho_{s}\left[\mathrm{~g} / \mathrm{cm}^{3}\right]\right)$ at the tested range, shows, for both types of sandstones, a linear relation with the $\sigma_{1}-\sigma_{2}$, and nonlinear relation to $\sigma_{1} / \sigma_{2}$ (Fig. $4 \mathrm{a}, \mathrm{b}$ ). 
a)

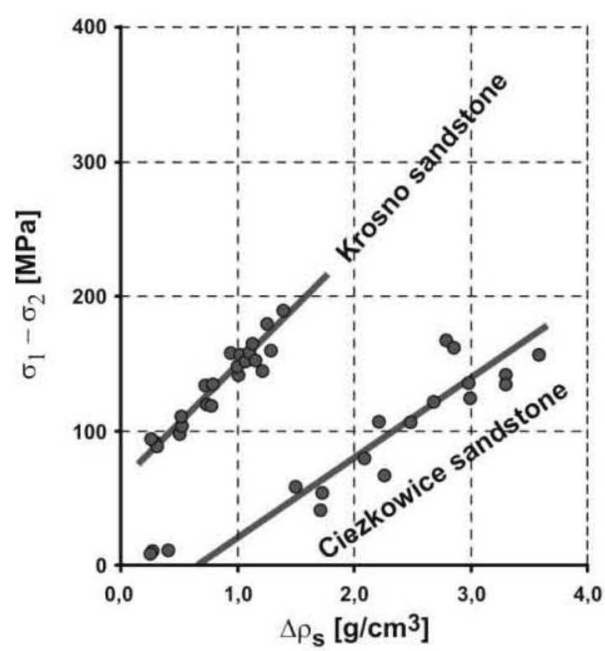

b)

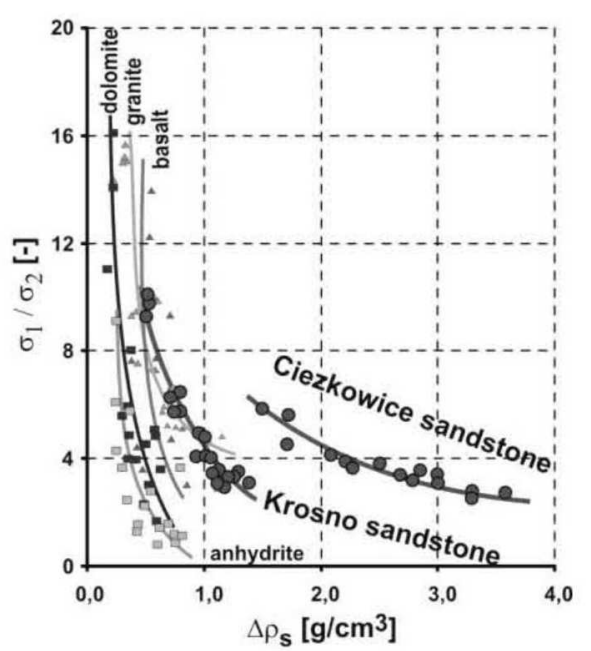

Fig. 4. Total increase in density $\left(\Delta \rho_{s}\right)$ at the threshold of dilatancy. a) Relation to $\sigma_{1}-\sigma_{2}$; b) Relation to $\sigma_{1} / \sigma_{2}$ for both sandstones with reference to the other rocks.

Rys. 4. Maksymalny wzrost gęstości objętościowej na progu makrodylatancji. a) w zależności od $\sigma_{1}-\sigma_{2}$; b) w zależności od $\sigma_{1} / \sigma_{2}$ na tle innych odmian litologicznych skał

The longitudinal wave velocity changes are related to paths of deformation, therefore their routes were simultaneously monitored with the axial, circumferential and volumetric strain characteristics (Fig. 5).

The total growth of longitudinal wave velocity $(\Delta \mathrm{Vp})$ takes place at the I stage (Fig. 6).

The share of the longitudinal wave velocity changes at the stage I to the total $(100 \%)$ changes is very high, and its relation to depth $(\mathrm{P}+\mathrm{T})$ is semi-regular in the Ciężkowice sandstone, and in the Krosno sandstone is random (Fig. 7).

At the stage II according to the depth $(\mathrm{P}+\mathrm{T})$ the role of a phase of compaction, similarly to impact on changes of density, diminishes and the role of the phase of elasticity increases in both types of sandstones. At the depth greater then $2000 \mathrm{~m}$ longitudinal wave growths were observed also in phase of microcraking (Fig. 8).

Changes of average maximum longitudinal wave velocity at various levels of simulated depth (P+T) are shown on diagrams (Fig. 9).

In the Krosno sandstone longitudinal wave velocity growth $(\Delta \mathrm{Vp})$ is related to the state of stress $\left(\sigma_{1}-\sigma_{2}\right)$. In the Ciężkowice sandstones such relation is not visible (Fig. 10).

The volume density changes together with the elastic wave velocity changes, according to the increasing depth, have a great impact on a reliability of a remote identification of lithology and engineering parameters of rocks and rock massifs. Consequently, the proper identification of rock lithology in seismic profiling cannot be satisfactory, as 


\section{a) Ciezkowice sandstone}

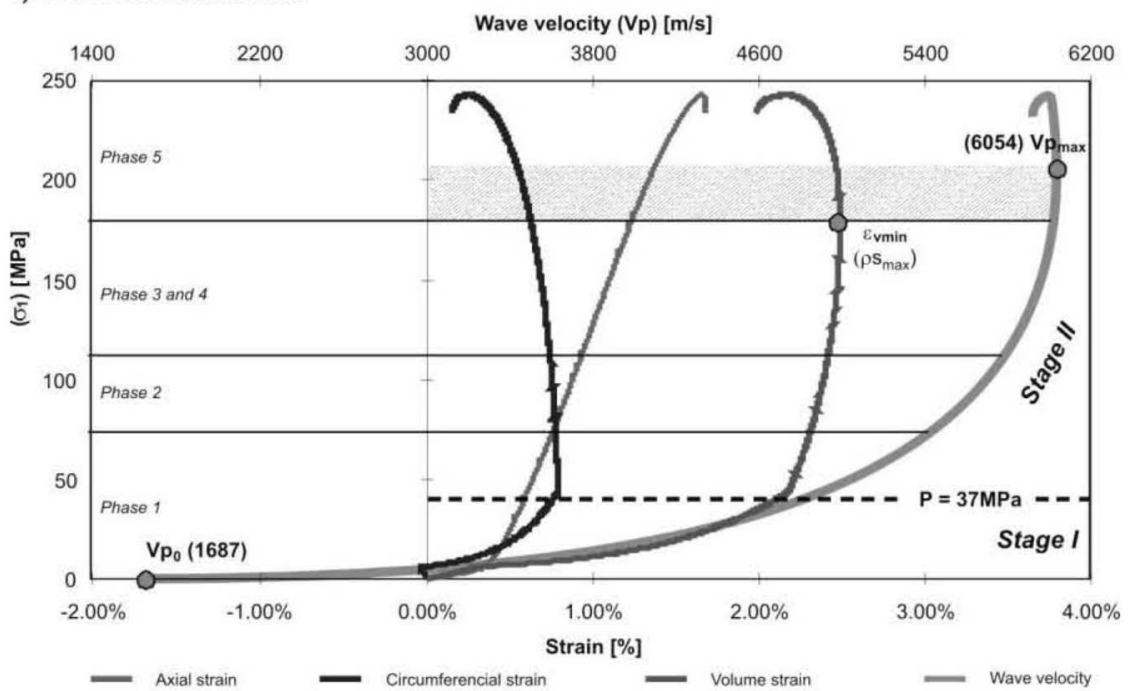

\section{b) Krosno sandstone}

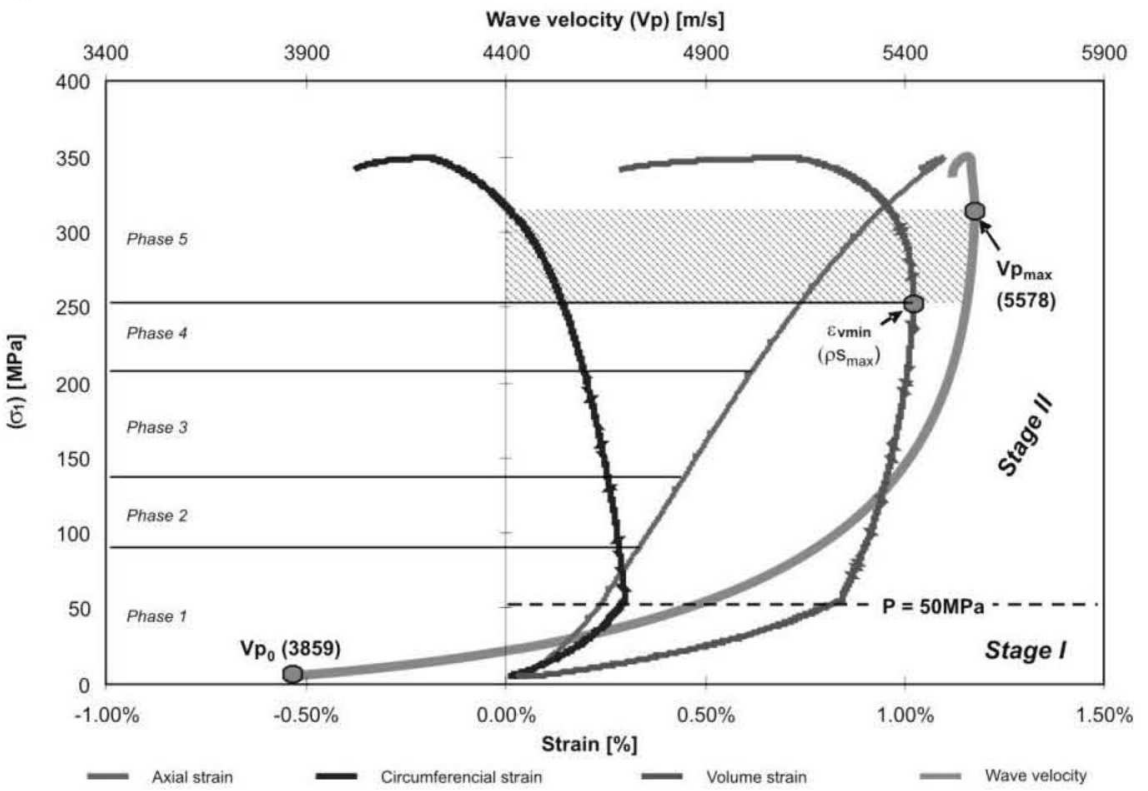

Fig. 5. Simultaneously recorded paths of deformation and longitudinal wave velocity. a) Ciężkowice sandstone, b) Krosno sandstone. Stage I - stage of stabilizing P+T, Stage II - stage of axial compression.

Rys. 5. Równolegle zapisane ścieżki deformacji i zmian prędkości fali podłużnej: a) piaskowiec ciężkowicki; b) piaskowiec krośnieński. I - etap stabilizacji P+T. II - etap ściskania osiowego 
a) Ciezkowice sandstone

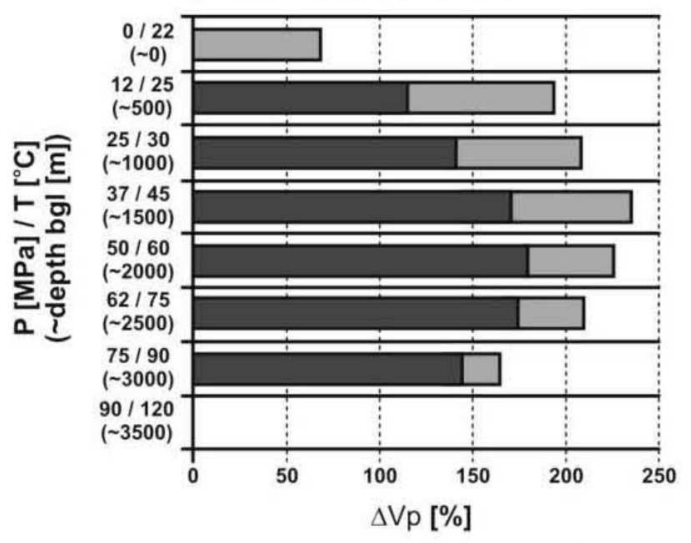

b) Krosno sandstone

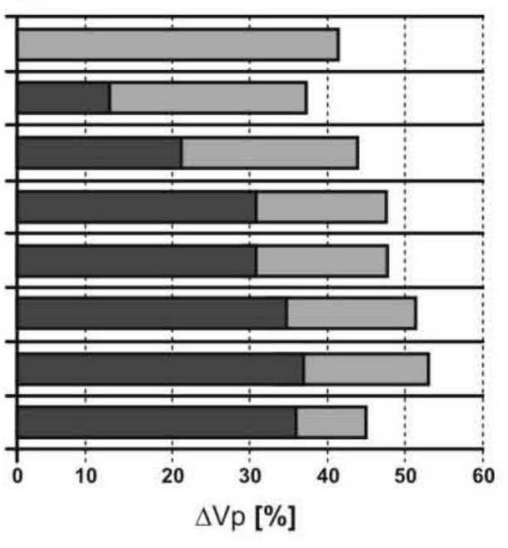

Stage II

Fig. 6. Increase of a wave velocity $(\Delta \mathrm{Vp})$ in $\%$ at various level of simulated depth $(\mathrm{P}+\mathrm{T})$. a) Ciężkowice sandstone, b) Krosno sandstone

Rys. 6. Wzrost prędkości fali podłużnej $(\Delta \mathrm{Vp}) \mathrm{w} \%$ na kolejnych poziomach symulowanej głębokości

$(\mathrm{P}+\mathrm{T})$. a) piaskowiec ciężkowicki; b) piaskowiec krośnieński

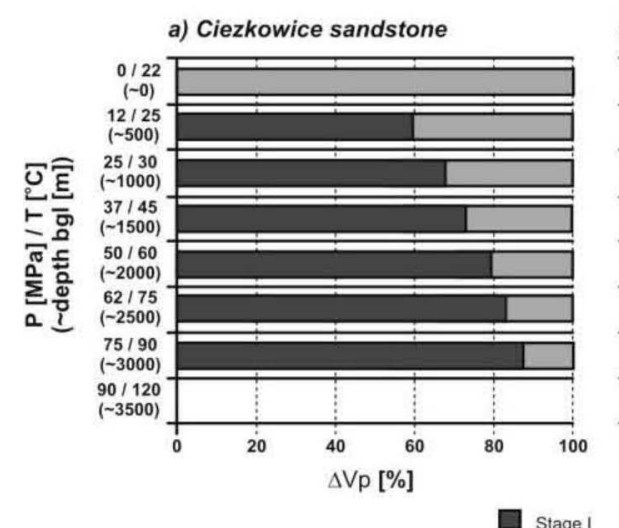

\section{b) Krosno sandstone}

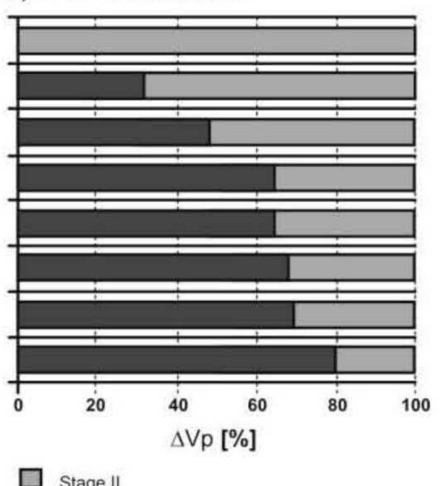

Fig. 7. Share of a longitudinal wave velocity increase $(\Delta \mathrm{Vp} \%)$ at stages I and II in a total velocity changes at various levels of simulated depth $(\mathrm{P}+\mathrm{T})$. a) Ciężkowice sandstone, b) Krosno sandstone. Rys. 7. Udział przyrostów prędkości fali podłużnej $(\Delta \mathrm{Vp} \%)$ na etapie I i II w całości zmian prędkości na kolejnych poziomach symulowanej głębokości $(\mathrm{P}+\mathrm{T})$. a) piaskowiec ciężkowicki; b) piaskowiec krośnieński 

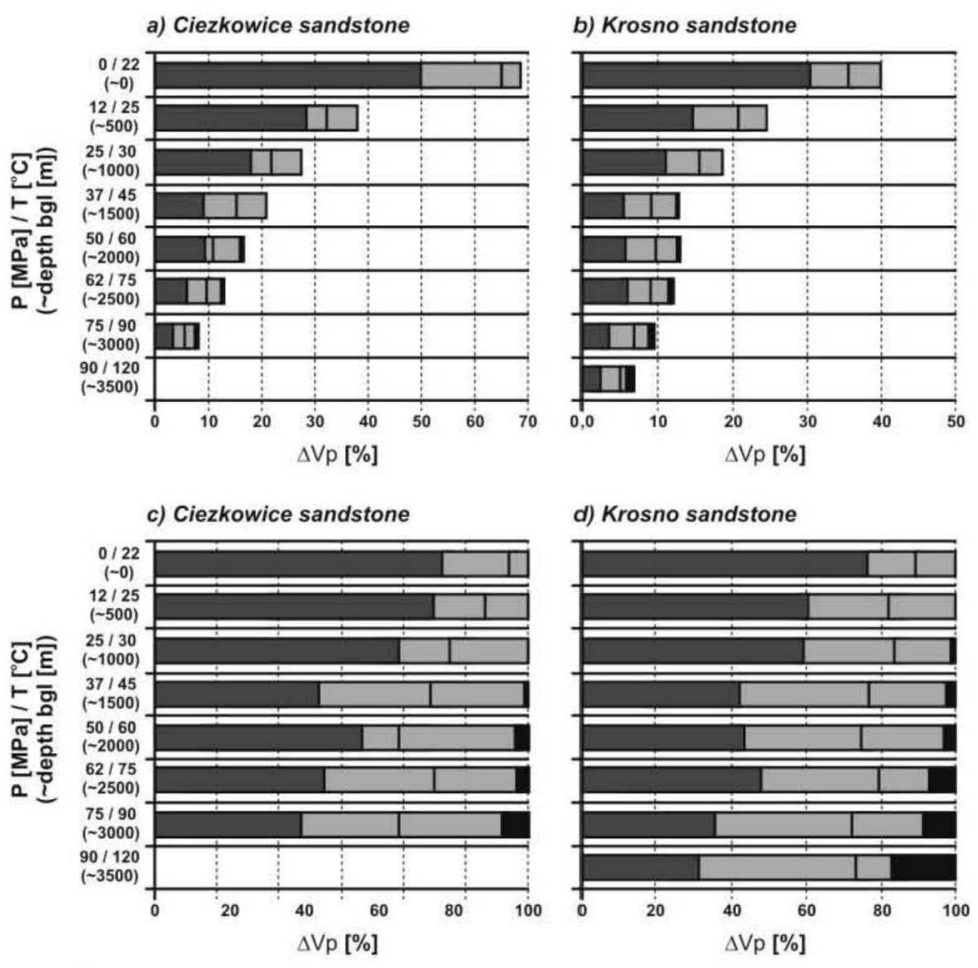

Phase of compaction (1)

$\square$ Phases of elastic deformations (2 and 3)

Phase of microcracking (4)

Fig. 8. Increase of longitudinal wave velocity at the compression stage II according to the $1^{\text {st }}, 2^{\text {nd }}$ and $3^{\text {rd }}$ as well as 4th phases of deformation at various levels of simulated depth $(\mathrm{P}+\mathrm{T})$. Upper - increase in wave velocity with the depth. Lower - share of the separate phases of deformation at total increase of

Vp (in \%). a, c) Ciężkowice sandstone, b, d) Krosno sandstone.

Rys. 8. Przyrost prędkości fali podłużnej na etapie ściskania osiowego (etap II) w poszczególnych (1, 2 i

3) fazach deformacji na kolejnych poziomach symulowanej głębokości (P+T). a, c) piaskowiec ciężkowicki, b, d) piaskowiec krośnieński

different rock types at certain depths may transfer elastic waves with similar velocity (Fig. 11).

In a view of presented graphs, the only reliable method of remote identification of rocks at great depth is a complex approach to determining the elastic wave velocity together with determination of rock volume density (right hand side of Fig. 11) or attenuation of wave propagation.

Velocity changes in relation to $\mathrm{P}+\mathrm{T}$ create also discrepancies between the static parameters of rocks determined by standard laboratory load tests, and the dynamic parameters, determined according to the wave velocity and density, as it is shown for Young's modulus on Fig. 12. 
a) Ciezkowice sandstone

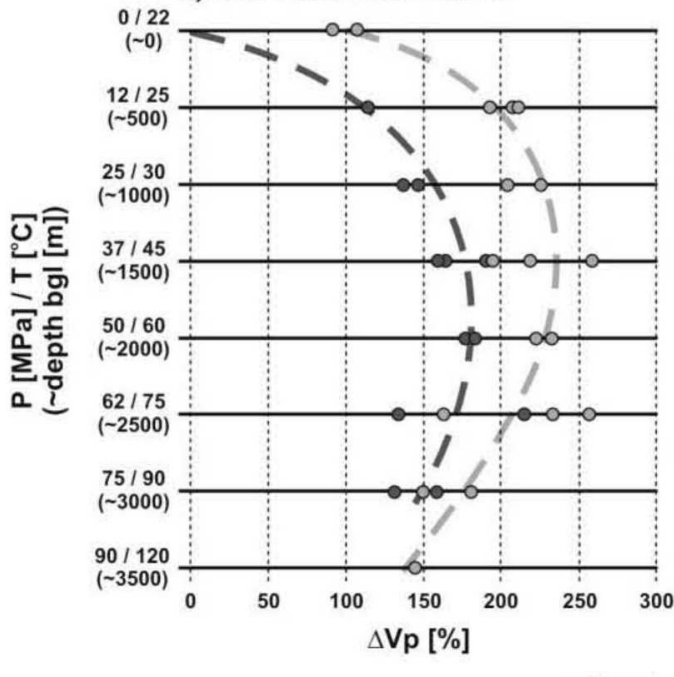

b) Krosno sandstone

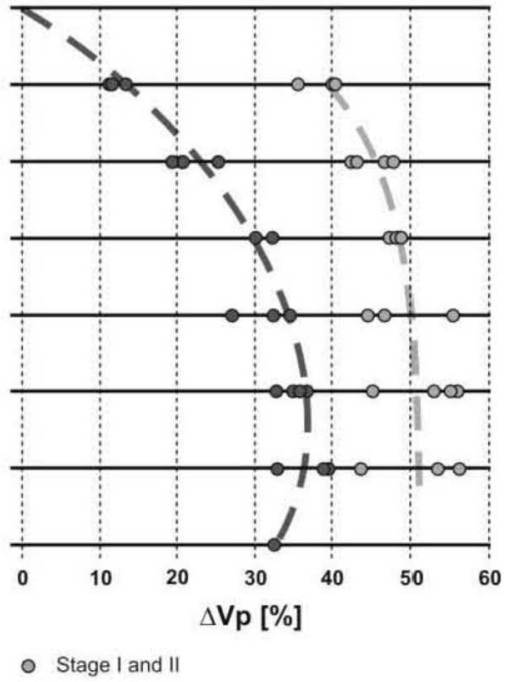

Fig. 9. Longitudinal wave velocity changes $(\Delta \mathrm{Vp})$ at various levels of simulated depth $(\mathrm{P}+\mathrm{T})$. a) Ciężkowice Sandstone, b) Krosno sandstone.

Rys. 9. Zmiany prędkości fali podłużnej $(\Delta \mathrm{Vp})$ na kolejnych poziomach symulowanej głębokości $(\mathrm{P}+\mathrm{T})$ : a) piaskowiec ciężkowicki, b) piaskowiec krośnieński

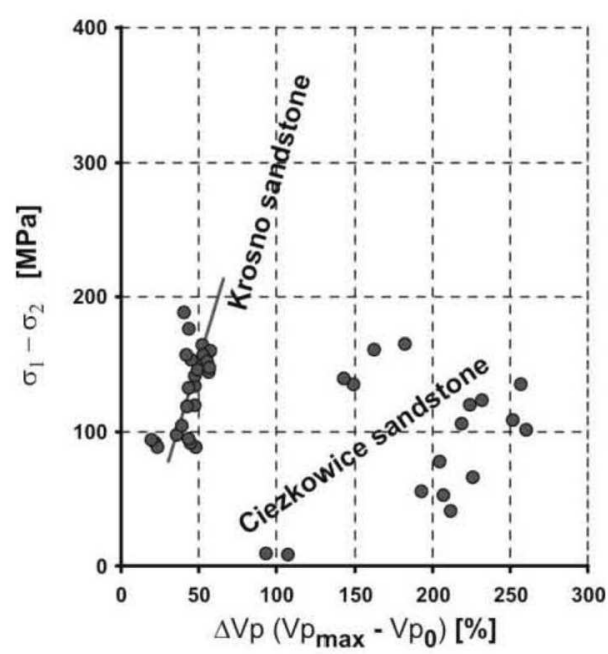

Fig. 10. Relation of longitudinal wave velocity ratio $\Delta \mathrm{Vp}[\%]$ to the state of stress condition $\left(\sigma_{1}-\sigma_{2}\right)$. Rys. 10. Zależność procentowej zmiany prędkości fali podłużnej $\Delta \mathrm{Vp}$ [\%] od naprężenia różnicowego

$$
\left(\sigma_{1}-\sigma_{2}\right)
$$




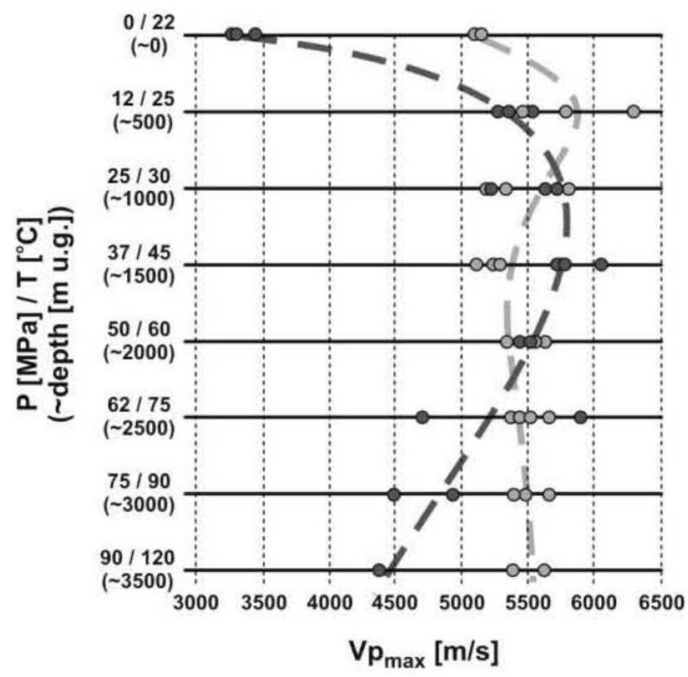

- Ciężkowice sandstone

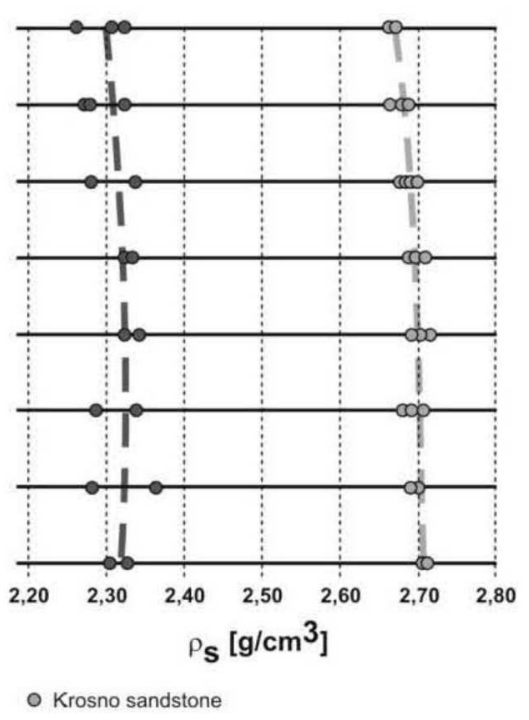

Krosno sandstone

Fig. 11. Elastic wave velocity (left) and volume density (right) according to variable state of (P+T) up to simulated depth $3500 \mathrm{~m}$ bgl.

Rys. 11. Maksymalna prędkość fali sprężystej (lewy) i największa gęstość objętościowa (prawy)w zależności od symulowanej głębokości do 3500 m p.p.t

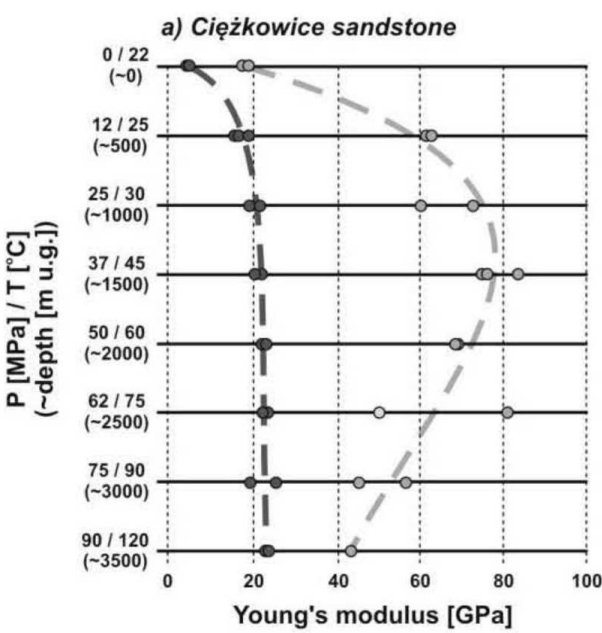

- static Young's modulus b) Krosno sandstone

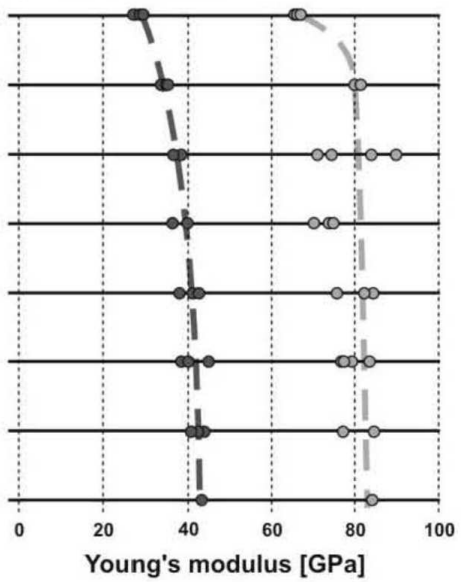

○ dynamic Young's modulus

Fig. 12. Discrepancies of the determined $\mathrm{E}_{s t}$ and $\mathrm{E}_{d}$ according to variable states of $(\mathrm{P}+\mathrm{T})$ up to simulated depth $3500 \mathrm{~m}$ bgl. a) Ciężkowice sandstone, b) Krosno sandstone.

Rys. 12. Zróżnicowanie wyznaczonych wartości $\mathrm{E}_{s t}$ i $\mathrm{E}_{d} \mathrm{w}$ zależności od symulowanej głębokości do 3500 m p.p.t. a) piaskowiec ciężkowicki, b) piaskowiec krośnieński 
The precise knowledge of the elasticity modulus (E) and the Poisson ratio $(v)$ is important in every kind of rocks engineering. An example from fracturing of rocks for improving productivity of wells is obviously supporting the above statement [2]. The calculated length, width, and spaces of the hydraulically forced fractures in a sandstone series in the hydrocarbon wells near Stezyca, are presented in Fig. 13. According to variance calculations with the basic formulas for the 2D models of Perkins et al. [3] with respect to variable circumferential stress $(\mathrm{P})$ up to $60 \mathrm{MPa}$, the impact of changes in Poisson ratio $(v)$ on the geometry of fractures was considerably small, circa $6 \%$. The impact of changes in a Young modulus was, however, much more significant. Therefore for the same rock, dependably on the state of stress, varying results in calculated length and surface area of fracture could be greater than $60 \%$, and in opening of fractures almost $40 \%$ (Fig. 13).
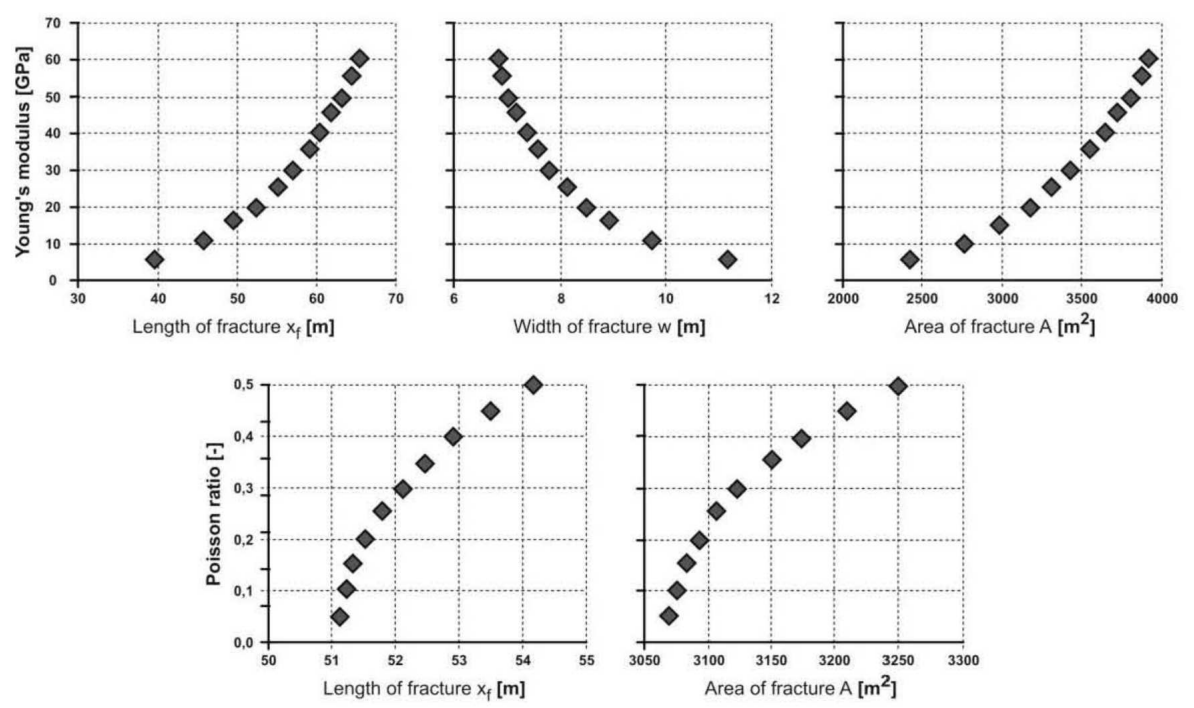

Fig. 13. Varying of calculated length of fracture (x) [in $\mathrm{m}$ ], width of fracture (w) [in $\mathrm{m}$ ], and area of fracture (A) [in $\mathrm{m}^{2}$ ] according to changes of Young's modulus (E) and Poisson ratio ( $v$ ) [from 2].

Rys. 13. Zmienność wyliczonej szerokości (w) [m], długości (x) [m] i powierzchni spękania (A) $\left[\mathrm{m}^{2}\right]$ w zależności od zmian modułu Younga (E) i współczynnika Poissona (v) [za Jarzębski, Pinińska 2000]

\section{Conclusions}

1. Impact of a high pressure $(\mathrm{P})$ and temperature $(\mathrm{T})$ deviates elastic wave velocity $(\mathrm{Vp})$, and a volume rock density $\left(\rho_{s}\right)$ makes remote recognition of geological rock mass unreliable; that may lead to wide error margin in a determination of rock's engineering properties. 
2. Deviations in volume density $\left(\rho_{s}\right)$ and the elastic wave velocity $(\mathrm{Vp})$ under impact of pressure $(\mathrm{P})$ and temperature $(\mathrm{T})$ differentiate their dynamics, related to the state of stress and phases of deformation; therefore, even inside the rock mass, the deviations may not be linear. The specific corrections, determined individually for each of rock-mass varieties should be applied according to recognized thermal and pressure conditions inside the massif.

3. Laboratory testing of a well recognized rock masses under high pressure and temperature improve the engineering-geological knowledge of a complex mechanics governing rock massifs. The tests of Ciężkowice and Krosno sandstones show that under high pressure and temperature, the density and elastic wave velocity change within several to several hundred percent (\%) range, dependably of physical properties of a certain rock.

4. The variable parameters cause high uncertainty level in a remote recognition of geological media; the extrapolation of surface geological or geophysical data into deep lying rocks is thus inconsistent. Subsurface remote sensing must be performed with extreme caution in each case.

\section{REFERENCES}

1. N. Barton, Rock Quality, seismic velocity, attenuation and anisotrpy. Taylor \& Francis/Balkema. Leiden, Netherlands, 1-729 2006.

2. S. JARZĘBSKI, J. PINIŃSKA, Analysis of influence of elasticity parameters on hydraulic cavitation of Stęzyca region rocks [in Polish], Przegląd Geologiczny, 48, 12, 1151-1155 2000.

3. T.K. Perkins, I.R. Kern, Width of hydraulic fractures, J.Petr.Tech. 271-276 1961.

4. J. Piniśska, A. Dziedzic, Simultaneous measurement of longitudinal wave velocity and process of elastic deformation of rocks under triaxal compression in high pressures and temperature [in Polish], Mat.Konf. „Geofizyka w Geologii i Górnictwie”. WNoZ UŚ, GIG, IGP PAN. 85-86 2010.

\section{ZMIANY GĘSTOŚCI OBJĘTOŚCIOWEJ I PRĘDKOŚCI FALI PODŁUŻNEJ SKAŁ FLISZOWYCH: PIASKOWCÓW CIĘŻKOWICKICH I KROŚNIEŃSKICH POD WPLYWEM WYSOKIEGO CIŚNIENIA I TEMPERATURY W WARUNKACH TRÓJOSIOWEGO ŚCISKANIA}

$$
\text { Streszczenie }
$$

Gęstość objętościowa skał oraz prędkość fal sprężystych są stosowane do identyfikacji właściwości i litologii skał na dużych, niedostępnych dla bezpośrednich obserwacji głębokościach. Znaczne ciśnienie (P) oraz wysoka temperatury $(\mathrm{T})$ powodują zmiany prędkości propagacji fali $(\mathrm{Vp})$ oraz gęstości objętościowej $\left(\rho_{s}\right)$, co utrudnia zdalne rozpoznanie odmiennych litologicznie skał oraz prowadzi do znacznych błędów w ocenie inżynierskiej ich parametrów. 
W wyniku laboratoryjnych badań wytrzymałościowych w komorze termociśnieniowej, w warunkach trójosiowego ściskania przy zróżnicowanych ciśnieniach obwodowych $\left(\mathrm{P}=\sigma_{2}=\sigma_{3}\right) \mathrm{w}$ przedziale od 0 do $90 \mathrm{MPa}$ i temperaturze (T) od 22 do $120^{\circ} \mathrm{C}$ (symulujących co $500 \mathrm{~m}$ interwały wzrostu głębokości od powierzchni do $3500 \mathrm{~m}$ ), słabo zwięzłe, różnoziarniste piaskowce ciężkowickie oraz zwięzłe, drobnoziarniste piaskowce z Mucharza, wykazały nieliniowy wzrost gęstości objętościowej do 1,4 to 4,0\% i dochodzący do $250 \%$ wzrost prędkości fali podłużnej w stosunku do wartości początkowej (warunki powierzchniowe). Zmiany zależały od ścieżki obciążania, faz deformacji oraz zróżnicowania litologicznego skały.

Remarks on the paper should be sent to the Editorial Office

no later than June 30, 2011
Received December 15, 2010 revised version March 24, 2011 